\title{
Transverse Testicular Ectopia: Two Case Reports
}

\author{
Transvers Testiküler Ektopi: Iki Olgu Sunumu

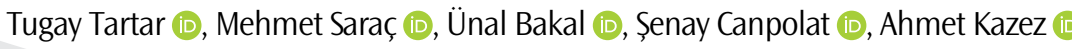

Transverse testicular ectopia (TTE) is a rare congenital anomaly caused by migration of the testes to the same half of the scrotum; it is associated with inguinal hernia. In addition, it is present along with persistent Müllerian duct syndrome (PMDS) in approximately $20 \%$ of patients. In such cases, Müllerian duct excision is recommended. In this article, we present two cases of TTE including one case of PMDS accompanied by TTE. Different approaches have been described in the treatment of TTE. Protection of testicular tissue and removal of the Müllerian duct, when TTE is present along with PMDS, are the basis of treatment.

Keywords: Transverse testicular ectopia, Persistent Müllerian duct syndrome, testis, surgery
Transvers testiküler ektopi (TTE) nadir görülen, her iki testisin birlikte aynı hemiskrotuma göç etmesi ile oluşan ve genellikle inguinal herni ile ilişkili olan konjenital bir anomalidir. Olguların yaklaşık \%20' sinde Persistant Müllerian Kanal Sendromu ile birliktelik vardır. Bu çalışmada 1 olgumuza Persistant Müllerian Kanal Sendromunun eşlik ettiği TTE'li 2 olgumuzu sunduk. TTE tedavisinde farklı yaklaşımlar tarif edilmiş̦ir. Tedavinin temeli testis dokularının korunması ve varsa Müllerian Kanalın çıkarılmasıdır.

Anahtar Kelimeler: Transvers testiküler ektopi, Persistant Müllerian kanal sendromu, testis, cerrahi
Bu çalıșma 7. Ulusal Pediatrik Üroloji Kongresi'nde sunulmuștur (26-30 Ekim, 2016, Girne, KKTC).

ORCID IDs of all the authors: T.T. 0000-00027755-4736; M.S. 0000-0002-6660-5243; Ü.B. 00000002-5140-8618; S.C. 0000-0003-2318-5653; A.K. 0000-0003-0440-3555.

Department of Pediatric Surgery, Firat University School of Medicine, Elazı̆ğ, Turkey

Address for Correspondence/Yazıșma Adresi: Tugay Tartar

E-mail: tugaytartar@gmail.com

Received/Geliș Tarihi: 12.05.2017

Accepted/Kabul Tarihi: 29.12.2017

(C) Copyright 2018 by Available online at istanbulmedicaljournal.org

(C) Telif Hakkı 2018 Makale metnine istanbultipdergisi.org web sayfasından ulaşılabilir.

\section{Introduction}

Transverse testicular ectopia (TTE) is a rarely seen congenital anomaly, generally associated with inguinal hernia, where both testes migrate into the same hemiscrotum. An ectopic testis may be situated in the contralateral hemiscrotum, inguinal canal, or internal inguinal ring. In most patients with TTE, a nonpalpable testis along with an ectopic testis associated with ipsilateral inguinal hernia is present. Furhtermore, TTE may be associated with hydrocele, disorders of sexual development, and karyotypic anomalies in nearly $20 \%$ of the cases, TTE is associated with Persistent Müllerian duct syndrome (PMDS) (1). Regression of Müllerian structures is expected in men. However, sometimes, these structures may be localized in the abdominal cavity or herniated through the inguinal canal. Although the mechanism of this pathologic descensus is unknown, various hypotheses have been suggested including descensus of both testes into the same canal because of a defect occurring during the fetal development of testes, premature fusion of Wolffian ducts, and origination of both testes from the same germinal structure (2).

Different approaches have been described in the treatment of TTE. In this article, we have presented two cases with TTE.

\section{Case Reports}

\section{Case Report 1}

A 9-year-old male was referred to our clinic with the absence of testis in the left hemiscrotum. He was operated at another center for right inguinal hernia. On physical examination, the testis could not be palpated in the left inguinal canal and left hemiscrotum. In the right hemiscrotum and the upper part of the scrotum, an anatomical formation thought to be two separate testes was palpated. On a scrotal ultrasound (US), both testes and epididymis were detected in the right hemiscrotum. The dimensions and echogenicities of both testes were within the normal limits. An US revealed that both spermatic chords passed through the right inguinal canal, but the left testis could not be visualized. On laparoscopic exploration, a patent left inguinal canal was seen. However, Müllerian duct remnants were not observed, and the vessels of two separate testes entered the right inguinal canal. On inguinal exploration, two separate ducts and two testicular structures, which were adhered to each other, were observed (Figure 1). The adhesions were excised, and two testes were separated from each other (Figure 2). Through an incision made on the scrotal septum, the left testis was fixed to the left and the right testis was fixed to the right hemiscrotum. The patient also underwent left inguinal hernia repair. No relevant medical problems were encountered 


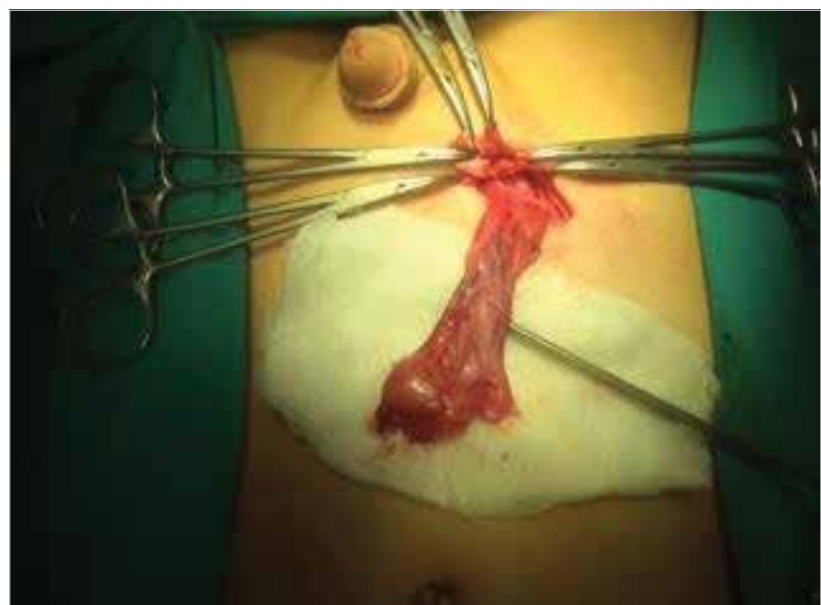

Figure 1. Passage of both spermatic chords through the right inguinal canal

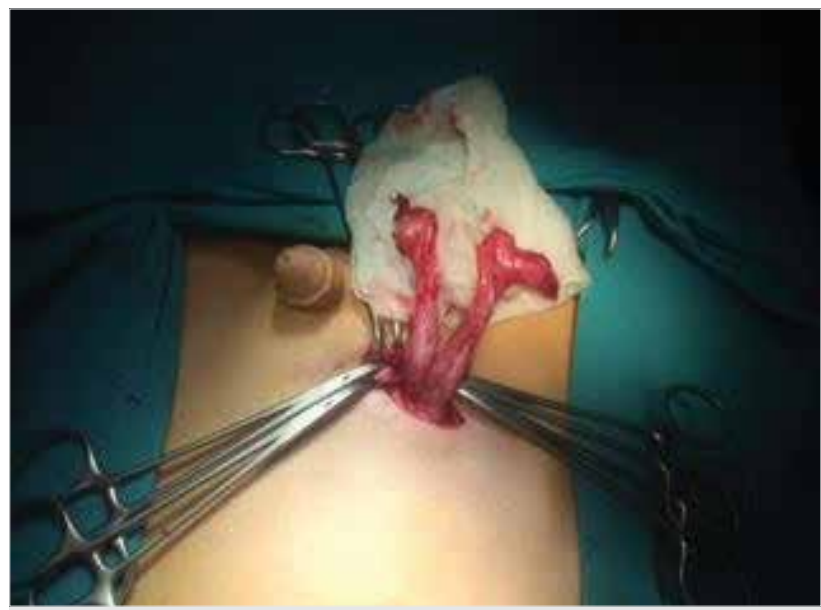

Figure 2. Excision of adhesions and separation of both testicular tissues

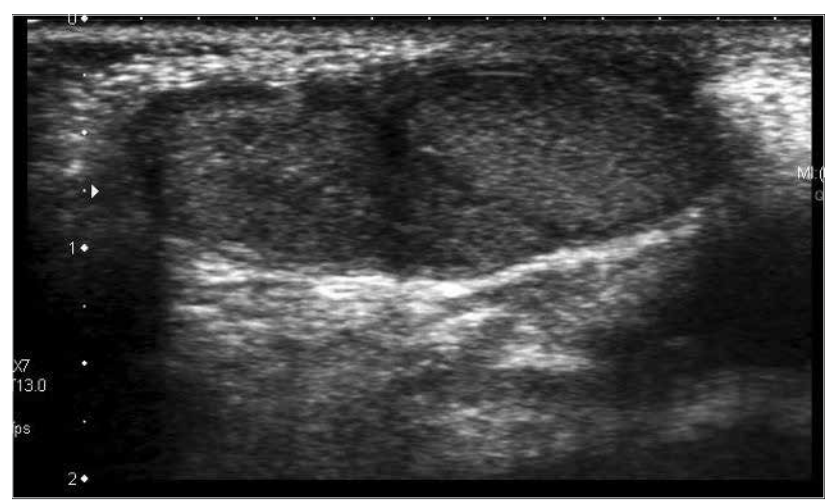

Figure 3. US image of a case with TTE

during patient follow-up. Written informed consent was obtained from parents of the patients who participated in this study.

\section{Case Report 2}

A 1-year-old male was referred to our clinic with the absence of testis in the left hemiscrotum. On physical examination, the testicular tissue could not be palpated in the left inguinal region and left hemiscrotum. The right testis was palpable in the right inguinal region. Furthermore, penile chordee was present. Karyotype test results confirmed a 46, XY karyotype. A scrotal US showed the right testis to be in the right inguinal region, and the testis had a homogenous parenchymal echogenicity. The left testis was located posterosuperior to the right testis. It was mobile within the intraabdominal cavity and had the same echogenicity as the right testis. Both spermatic chords passed through the right inguinal canal (Figure 3). On laparoscopic exploration, it was observed that the left inguinal canal was occluded and the vascular structures expected to pass through the canal were absent; furthermore, rudimentary tissues were detected at the entry of the canal. The right inguinal canal was patent, and the testis and vascular structures at the entry of the right inguinal canal were observed. On inguinal exploration, the testis and its appendages were observed in the right inguinal canal; furthermore, a second testis and its appendages were observed at the entry of the canal. Both testes formed a "V" configuration and joined at a single point. Through a single incision on the scrotal septum, the left testis was placed in the left hemiscrotum and the right testis was fixed in the right hemiscrotum. The patient also underwent a right inguinal hernia repair. Bilateral testicular biopsies were performed to confirm the presence of testicular tissue. The 4-year follow up period of the patient was uneventful. Written informed consent was obtained from parents of the patient who participated in this study.

\section{Discussion}

Anomalies associated with TTE have been categorized into three types:

Type 1: TTE associated with inguinal hernia only (40\%-50\%)

Type 2: TTE associated with PMDS (30\%)

Type 3: TTE associated with sexual development disorders, hypospadias, and scrotal anomalies (20\%) (3)

PMDS is a male pseudohermaphroditism that develops secondary to a deficient release of Müllerian inhibiting factor (MIF) from fetal Sertoli cells (4). Because MIF can be measured in serum up to 2 years of age, it can aid in preoperative diagnosis (5). The gene responsible for MIF release is situated on the short arm of chromosome 19 (6). As a typical feature of PMDS, both testes are palpated in the same hemiscrotum. In such cases, for the establishment of preoperative diagnosis, US, computed tomography, magnetic resonance imaging, or magnetic resonance venography can be used (4). Reportedly, in nearly $65 \%$ of the cases, diagnosis of TTE is made during surgery for inguinal hernia (7). Our first presented case was referred to our clinic after being operated for inguinal hernia and had a contralateral nonpalpable testis, whereas the second case was brought with a nonpalpable testis. In both the presented cases, the diagnosis of TTE was made based on US. Furthermore, in one of the cases, PMDS was diagnosed during diagnostic laparoscopy, and this patient was not evaluated ultrasonographically.

In PMDS, intra-abdominal testis and relevant malignancy rates reported for PMDS demonstrate similarities, so in cases with PMDS, necessity for orchiectomy has been indicated for a testis that cannot be brought down to the bottom of the scrotum (8). In addition, because the separation of the uterus and fallopian tubes from the testis and vas deferens may cause injury to surrounding arteries, impairing testicular vascularization (as indicated in some reports), if the Müllerian duct remnants do not complicate orchiectomy, these remnants should not be excised (5). As the first stage in the 
surgical treatment of PMDS, gonadal biopsy followed by orchiopexy has been recommended by some authors, whereas others have reported uselessness of testicular biopsy in patients with a male karyotype (4). In one of our patients, during laparoscopic exploration of the undescended testis, rudimentary tissues were observed at the entry of the inguinal canal, and testicular biopsy performed during orchiopexy helped confirm the presence of testicular tissue. Furthermore, we decided not to remove the rudimentary tissues because of the possibility of injury to testicular vessels.

No malignant tumors originating from the Müllerian duct remnants (tuba uterina, uterus, and one-third of the vagina) have been reported because these structures are probably not affected by estrogens. Therefore, as indicated in some case reports, removal of these structures does not render additional benefits to the patient (4).

\section{Conclusion}

In the management of TTE, an ectopic testis should be placed in its normal anatomical position through transseptal orchiopexy or extraperitoneal transposition. In addition, in cases with TTE, PMDS should be kept in mind, and the Müllerian duct remnants should be investigated via diagnostic laparoscopy. In such cases, because a malignancy may develop, the Müllerian duct remnants should be removed to as much extent as possible without traumatizing the testis and its annexes. The patients should be followed up for a long time to check for infertility and malignancy.

Informed Consent: Written informed consent was obtained from parents of the patients who participated in this study. .

Peer-review: Externally peer-reviewed.

Author contributions: Concept - T.T., M.S.; Design - T.T., M.S., Ü.B.; Supervision - A.K.; Resource - T.T., Ș.C.; Materials - T.T., M.S., ÜB.; Data Collection and/or Processing - T.T., M.S., Ü.B.; Analysis and/or Interpretation - T.T., A.K.; Literature Search - T.T., S.C.; Writing - T.T.; Critical Reviews - A.K.

Conflict of Interest: Authors have no conflicts of interest to declare.

Financial Disclosure: The authors declared that this study has received no financial support.
Hasta Onamı: Yazılı hasta onamı bu çalıșmaya katılan hastaların ailelerinden alınmıștır.

Hakem Değerlendirmesi: Dış Bağımsız.

Yazar Katkıları: Fikir - T.T., M.S.,; Tasarım - T.T., M.S., Ü.B.,; Denetleme A.K.; Kaynaklar - T.T., S.C..; Malzemeler - T.T., M.S., ÜB.Veri Toplanması ve/ veya ișlemesi - T.T., M.S., Ü.B., ; Analiz ve/veya Yorum - T.T., A.K. , ; Literatür taraması - T.T., Ş.C. , ; Yazıyı Yazan - T.T.; Eleștirel İnceleme - A.K. .

Çıkar Çatıșması: Yazarlar çıkar çatışması bildirmemișlerdir.

Finansal Destek: Yazarlar bu çalıșma için finansal destek almadıklarını beyan etmişlerdir.

\section{References}

1. Karnak I, Tanyel FC, Akçören Z, Hiçsönmez A. Transverse testicular ectopia with persistent müllerian duct syndrome. J Pediatr Surg 1997; 32: 1362-4. [CrossRef]

2. Gupta RL, Das P. Ectopia testis transversa. J Indian Med Assoc 1960; 35: 547-9.

3. Ramareddy RS, Alladi A, Siddappa OS. Ectopic testis in children: experience with seven cases. J Pediatr Surg 2013; 48: 538-41. [CrossRef]

4. Tunçay S. Persistent Müllerian Duct Syndrome with Transverse Testicular Ectopia and Hernia Uteri Inguinalis: A Case Report. Turk J Urol 2003; 29: 215-8.

5. Martin EL, Bennet AH, Cromia WJ. Persistent Müllerian duct syndrome with transverse testicular ectopia and spermatogenesis. J Urol 1992; 147: 1615-7. [CrossRef]

6. Cohen-Hanguenauer O, Picard JY, Mattéi MG, Serero S, Nguyen VC, de Tand MF, et al. Mapping of the gene for antimüllerian hormone to the short arm of human chromosome 19. Cytogenet Cell Genet 1987; 44: 2-6. [CrossRef]

7. Gauderer MW, Grisoni ER, Stellato TA, Ponsky JL, Izant RJ Jr. Transverse testicular ectopia. J Pediatr Surg 1982; 17: 43-7. [CrossRef]

8. Berkmen F. Persistent müllerian duct syndrome with or without transverse testicular ectopia and testis tumors. Br J Urol 1997; 79: 122-6. [CrossRef]

Cite this article as: Tatar T, Saraç M, Bakal Ü, Canpolat Ş, Kazez E. Transverse Testicular Ectopia: Two Case Reports. İstanbul Med J 2018; 19: 184-6. 